\title{
INOVASI KURIKULUM BAHASA \\ ARAB MADRASAH ALIYAH BERBASIS KONTRUKTIVISME
}

\author{
Prabowo Adi Widayat \\ Program Pascasarjana UIN Sunan Kalijaga Yogyakarta \\ E-mail:Mahabbatullah10@gmail.com
}

\begin{abstract}
The curriculum used in each educational institution is a guideline that contains a description in general terms about the fine points of the learning material that must be implemented by educational institutions through teachers and students in an atmosphere of learning. The Arabic language as a compulsory subject in the madrasah aliyah should have a curriculum to suit the needs and challenges of the times. Arabic language curriculum must emphasize the importance of communicative and scientific approach in learning, because both approaches can accommodate the language learners practice and theoretically. Constructivism become part of current curriculum innovation. This theory emphasizes the importance of building knowledge gained with the sturdy cognition through communicative and interactive learning experiences between teachers and students in the school environment. In the Arabic language curriculum innovation, this theory gives the principles should be implemented including the following; physical learning material knowledge, knowledge of mathematical logic that are structural or based on norms of knowledge is studied, and the social sciences that emphasized the importance of communicative interaction in diverse environments.
\end{abstract}

Key Word: Curriculum, Arabic Language, Constructivism 


\begin{abstract}
Abstrak
Kurikulum yang digunakan di setiap institusi pendidikan merupakan pedoman yang memuat deskripsi secara umum mengenai pokokpokok materi pembelajaran yang harus diimplemetasikan oleh Institusi Pendidikan melalui guru dan siswa dalam suasana pembelajaran. Bahasa Arab sebagai mata pelajaran wajib di Madrasah Aliyah haruslah memiliki kurikulum yang sesuai dengan kebutuhan dan tantangan zaman. Kurikulum bahasa Arab haruslah menekankan pentingnya pendekatan komunikatif dan saintifik dalam pembelajaran, karena kedua pendekatan ini dapat mengakomodasi para pembelajar bahasa secara teoritik dan praktek. Konstruktivisme menjadi bagian dari inovasi kurikulum saat ini. Teori ini menekankan pentingnya membangun pengetahuan yang diperoleh dengan kognisi yang kokoh melalui pengalaman pembelajaran komunikatif dan interaktif antara guru dan siswa di lingkungan sekolah. Dalam inovasi kurikulum bahasa Arab teori ini memberikan prinsip-prinsip yang harus dilaksanakan yang diantaranya sebagai berikut; pengetahuan fisik materi pembelajaran, pengetahuan logika-matematika yang bersifat struktural atau berdasarkan kaidah-kaidah keilmuan yang dipelajari, dan pengetahuan sosial yang menekankan pentingnya interaksi komunikatif di lingkungan yang beragam.
\end{abstract}

Kata Kunci: Kurikulum, Bahasa Arab, kontruktivisme

\title{
A. Pendahuluan
}

Perkembangan pembelajaran bahasa Arab di Indonesia tentunya kuat dipengaruhi oleh sistem pendidikan nasional yang mengikutsertakan bahasa Arab sebagai bahasa Asing dengan tambahan tersendiri yakni sebagai kunci untuk mempelajari dua sumber utama ajaran Islam, yakni al-Qu'ran dan as-Sunnah. Oleh karenanya, kurikulum menjadi penting untuk disesuaikan dengan sistem pendidikan nasional yang memperhatikan penuh perkembangan zaman sehingga menjadi landasan pembelajaran yang inovatif dan akomodatif bagi para penyelenggara pendidikan. Penyesuaian kurikulum terhadap kebutuhan dan tantangan 
modernisasi di segala bidang tentunya menjadi dasar pemikiran para penggiat pendidikan dan khususnya mereka yang berkecimpung dalam proses pembelajaran bahasa Arab untuk dapat memformulasikan kurikulum baru melalui serangkaian teorisasi dari kondisi lingkungan belajar oleh para pakar, guru, maupun penyelenggara pendidikan pada umumnya.

Kurikulum yang didesain secara berkelompok merupakan hasil olah pikir dan batin para penggiat pendidikan terhadap kondisi lingkungan belajar masa kini yang bertujuan pokok untuk mengarahkan proses pembelajaran yang berorientasi pada kebutuhan dan perkembangan siswa. Oleh karenanya, inovasi kurikulum menjadi sebuah keniscayaan dan keharusan untuk mewujudkan proses pembelajaran yang baik dan menghasilkan output yang kompetitif dan akomodatif terhadap kebutuhan dan perkembangan zaman. Komposisi kurikulum tidaklah sebatas rangkaian deskriptif kompetensi inti dan kompetensi dasar yang nantinya dapat dijabarkan secara mandiri oleh para guru yang mengajarkan mata pelajaran tertentu. Namun sebaliknya, kurikulum haruslah memuat landasan filosofis pembelajaran yang berkiblat pada aspek sosiohumanistik yang merepresentasikan manusia sebagai human being dalam kehidupan sehari-hari.

Relasi kurikulum bahasa Arab dan epistemologi sebagai dasar inovasi dapat diwujudkan melalui tataran teoritis maupun pragmatis. Teori yang mendasari kurikulum haruslah yang mengarahkan kepada pembelajaran yang interaktif dan komunikatif sehingga dalam penyusunan materi pembelajaran dapat berimplikasi pada proses berkomunikasi interaktif dalam bingkai keragaman karakter budaya dan sosial yang kemudian menghasilkan tujuan akhir pembelajaran yang sesuai dengan alur prosesnya. Oleh karenanya, kurikulum ini merupakan pedoman pembelajaran yang didasarkan pada rancangan sistematik dan koordinatif 
yang bertujuan untuk menghasilkan output pembelajaran yang disepakati dalam suatu sistem pendidikan sehingga kurikulum menjadi jalan bagi mereka para guru untuk mentransmisikan pengetahuan kepada para siswa agar mampu memperluas jaringan keilmuan yang telah diinformasikan secara umum oleh guru melalui pembelajaran di kelas ${ }^{1}$.

Kurikulum 2013 yang berpijak pada scientific approach ${ }^{2}$ pada mata pelajaran bahasa Arab bertujuan khusus untuk menghayati dan mengamalkan ajaran Islam melalui dua sumber utama, yakni al-Qur'an dan Hadist ${ }^{3}$. Selain itu juga dalam keputusan Menteri Agama Republik Indonesia nomor 165 tahun 2014 tentang kurikulum 2013 mata pelajaran pendidikan agama Islam dan bahasa Arab pada madrasah menyatakan bahwa maksud dan tujuan kurikulum 2013 di madrasah pada umumnya adalah untuk mengembangkan potensi peserta didik menuju kemampuan bernalar reflektif untuk menjadi problem solver yang produktif, inovatif, dan afektif di kehidupan sosial yang tentunya dilandasi dengan keimanan yang kokoh dan keilmuan yang mapan dan kompetitif. Oleh karenanya, kehadiran kurikulum 2013 di madrasah tentunya menjadi tantangan

1 Muhajir, Śulāśiyah al-'Uqul Nabil Ali Sebagai Epistemologi Kurikulum Bahasa Arab di Indonesia (Perspektif Struktural-Fungsional), Disertasi (Yogyakarta: Program Pascarsarjana UIN Sunan Kalijaga Yogyakarta, 2015), h. 25.

2 Pendekatan saintifik yang dijadikan pijakan dalam penerapan kurikulum 2013 adalah pendekatan pembelajaran yang menekankan pada aspek pengamatan, pertanyaan, percobaan, asosiasi, dan komunikasi. Selain itu juga, pendekatan saintifik juga dimaksudkan untuk memberikan arahan dan pemahaman kepada para siswa untuk mengenal, memahami, menguraikan pengetahuan yang didapat dalam proses pembelajaran dengan menggunakan pendekatan ilmiah yang akhirnya hasil analisis yang didapat bersifat informatif, akomodatif, koordinatif. Selain itu juga pendekatan saintifik yang diterapkan dalam pembelajaran berfungsi untuk menggali informasi yang sesuai dengan materi pembelajaran melalui proses pencarian, verifikasi data, dan menyajikan data tersebut untuk bisa dintindaklanjuti dalam produksi keilmuan baru. (lihat Daryanto, Pendekatan Pembelajaran Saintifik Kurikulum 2013, (Yogyakarta: Gava Media, 2014), h. 54

3 Direktorat Pendidikan Madrasah Kemenag RI, Durūsu al-Lughah al-'Arabiyyah Buku Guru Bahasa Arab Pendekatan Saintifik Kurikulum 2013 untuk Kelas X Madrasah Aliyah, (Jakarta: Dirjen Pendidikan Madrasah Kemenag RI, 2014), h. 7. 
tersendiri sekaligus tuntutan untuk meningkatkan kualitas proses dan hasil pembelajaran.

\section{B. Pembahasan}

Belajar dalam konteks kekinian merupakan proses transmisi dan transformasi secara periodik untuk menginovasi kehidupan menjadi lebih mapan dan kondusif. Belajar pada umumnya juga dipahami sebagai proses pendewasaan peserta didik dari ketidaktahuan dan ketidakpahaman terhadap sesuatu menjadi paham dan tahu terhadap sesuatu tersebut yang tentunya berimplikasi secara keseluruhan terhadap kehidupannya. Selain itu juga, terdapat istilah pembelajaran yang sering kita dengar dan laksanakan yang dipahami sebagai suatu rangkaian operasional yang menjadikan seluruh elemen untuk berkontribusi dalam proses tersebut yakni belajar bersama-sama mencari pengetahuan baru serta solusi terhadap problematika yang mengitari kehidupan umat manusia dengan pendekatan-pendekatan keilmuan yang proporsional dan objektif.

Pembelajaran yang dilaksanakan di sekolah dan adrasah tidak akan terlepas dari fondasi pokok, yakni kurikulum. Dengannya, tujuan pendidikan nasional yang telah disepakati dalam bentuk undang-undang dapat terlaksana secarabertahap melalui implementasikurikulum disetiap materi pembelajaran. Kurikulum tidak selamanya berbentuk rangkaian arahan-arahan akademik yang bersifat operasional, namun ia juga harus menjadi tiang pendidikan yang kokoh untuk menjadikan umat manusia seutuhnya dengan segala potensi yang melekat pada diri mereka. Maka, terkait dengan hal ini terdapat peraturan menteri pendidikan nasional nomor 41 tahun 2007 tentang standar proses satuan pendidikan dasar dan menengah menjelaskan bahwa dalam penyelenggaraan pendidikan terdapat terdapat prinsip fundamental dalam penyelenggaraan reformasi 
pendidikan yakni proses pembudayaan dan pemberdayaan peserta didik yang berlangsung sepanjang hidup.

Kurikulum di institusi pendidikan merupakan sistematika landasan keilmuan untuk dapat dijabarkan seluas-luasnya oleh pemangku kebijakan di sekolah atau madrasah yang kemudian dilaksanakan secara berkelompok oleh para guru dan siswa melalui pembelajaran yang terarah. Selain itu juga, kurikulum menjadi pedoman institusional setelah undang-undang yang disahkan dan disepakati oleh pemerintah pusat yang didalamnya mencakup beragam petunjuk akademik berbasis tujuan pendidikan nasional. Proses inovasi atau pengembangan kurikulum bahasa Arab merupakan suatu keniscayaan dan kewajiban di tengahtengah modernisasi segala bidang sehingga memerlukan suatu kajian komprehensif dan mengakomadasi para pelaksana kurikulum bahasa Arab di sekolah maupun madrasah. Adapun kajian tersebut meliputi aspek filosofis, yuridis, dan teoritis yang kaitannya dengan pembelajaran bahasa Arab di Madrasah Aliyah.

Konstruktivisme sebagai falsafah epistemologi dan teori belajar memiliki sumbangsih besar bagi penyelenggaraan pendidikan khususnya di Madrasah Aliyah. Falsafah epistemologi senantiasa mengkaji dan mempertanyakan pengetahuan tentang bagaimana manusia sebagai agent ofknowledge untuk menggunakan pengetahuannya secara seksama melalui beragam inovasi dan eksperimentasi dari fenomena alam semesta untuk berkontribusi membangun masyarakat yang berperadaban adiluhung dalam segala bidang. Secara falsafi, konstruktivisme merupakan serangkaian konstruksi pengetahuan yang diperoleh dan digunakan oleh manusia sebagai hasil ijtihad ilmiah rasionalistis yang disebabkan oleh realita konstruksi kognitif melalui aktivitas-aktivitas eksperimentatif oleh manusia melalui bidang tertentu ${ }^{4}$. Oleh karenanya, belajar dalam

4 Paul Suparno, Filsafat Konstruktivisme dalam Pendidikan, (Yogyakarta: Kanisius, 1997), h. 18. 
perspektif konstruktivisme merupakan proses membangun pengetahuan yang didasarkan dengan realita pengalaman yang ada di lingkungan sekitar sehingga proses ini berimplikasi pada penguatan kognisi sebagai basis utama konstruksi keilmuan yang siswa dapatkan melalui komunikasi-komunikasi interaktif yang dirangkai dalam pengalaman belajar. Dalam bidang kurikulum konstuktivisme dijadikan landasan teoritik untuk menjabarkan proses pembelajaran di kelas yang dipahami sebagai proses pembentukan makna yang distimulus oleh serangkaian penglihatan, pendengaran, dan perasaan yang dipengaruhi oleh konstruksi pengetahuan sederhana yang dimiliki oleh peserta didik. Oleh karenanya, serangkaian penglihatan, pendegaran, dan perasanan yang ilmiah akan berimplikasi pada pengalaman otentik peserta didik setelah menyelesaikan pembelajaran di kelas ${ }^{5}$. Dengan demikian kurikulum yang dibentuk dengan basis konstruktivisme akan dapat menghilangkan sisi tekstualisasi menuju kontekstualisasi materi pembelajaran yang menjadikan para siswa mampu bergaul dengan segudang realita yang muncul di masyarakat luas.

\section{Kurikulum Bahasa Arab Madrasah Aliyah Tahun 2013}

Pembentukan kurikulum sejatinya di landasi oleh falsafah pendidikan yang kokoh dan akomodatif terhadap kebutuhan dan tuntutan zaman. Selain itu juga, aspek historis menjadi rujukan dan refleksi untuk mendesain atau menginovasi kurikulum yang proporsional agar mampu menjawab tantangan di era masa kini. Aspek historis dipahami sebagai sejarah perjalanan pendidikan di suatu negara atau komunitas tertentu yang ditinjau dari aspek institusional maupun kegiatan klasikal. Selain itu juga, komponen lainnya yang harus ada dalam kurikulum adalah aspek sosial dan psikologis yang berfungsi sebagai proses kontekstualisasi dan pedoman pedagogis

5 Ibid, hal. 61 
dalam penyelenggaraan pendidikan di sekolah. Oleh karenanya kurikulum yang baik dan benar sekaligus menjadi jawaban akan kebutuhan peradaban manusia haruslah diposisikan sebagai sentra pencerdasan manusia-manusia yang nantinya akan menjadi sosok cendekiawan atau intelektual yang berbudaya, beragama, dan tangguh dalam bersosialisasi di masyarakat yang majemuk. Berikut ini sebuah visualisasi proses inovasi kurikulum yang dapat dilaksanakan di sekolah maupun madrasah.

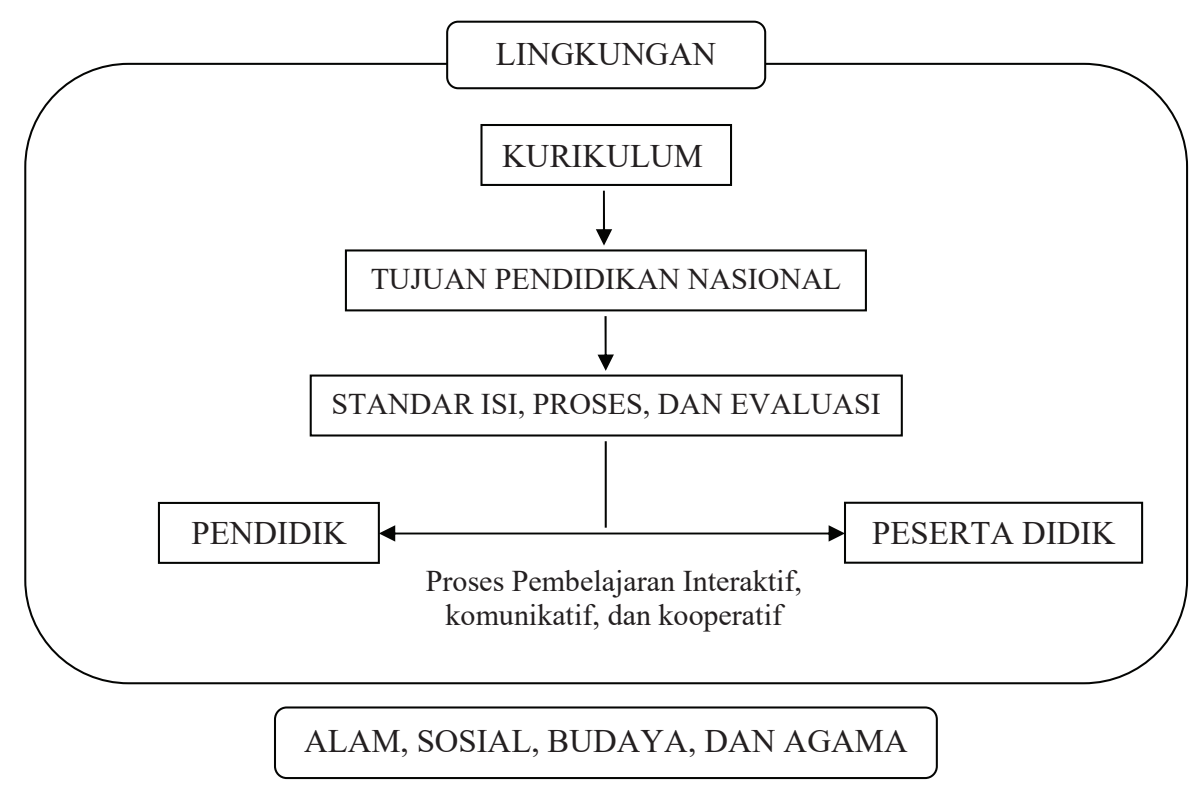

Gambar 2.1.

Desain kurikulum yang tercipta dari hasil konsensus para pemerhati dan penggiat pendidikan merupakan proses sistematis dan reflektif dari penafsiran teoritik prinsip-prinsip pembelajaran ke dalam suatu rancangan konstruktif yang meliputi komponen instruksional, 
kegiatan pembelajaran, sumber belajar, dan evaluasi ${ }^{6}$. Kurikulum sebagai pedoman akademik yang dijalankan oleh guru dan murid melalui materi-materi pembelajaran harus mampu mengarahkan para siswa mampu menggapai keberhasilan yang diharapkan oleh seluruh pihak yang bertanggung jawab dalam penyelenggaraan pendidikan. Selain itu juga terdapat sebuah pandangan bahwa kurikulum memiliki empat dimensi pengertian yang saling berkaitan yakni; kurikulum merupakan serangkaian sebuah ide, kurikulum merupakan dokumentasi deskriptif yang muncul akibat ide tersebut, kurikulum merupakan sebuah realita yang ditangkap oleh sekelompok ahli atau pakar yang kemudian mereka susun secara sistematis untuk dapat menjawab, mengelola, dan membentuk apa saja yang terdapat di dalam realita tersebut melalui proses pembelajaran di sekolah, dan kurikulum merupakan serangkaian hasil pembelajaran yang didasarkan oleh implementasi kurikulum di sekolah atau di madrasah ${ }^{7}$.

Kurikulum 2013 bertujuan untuk mempersiapkan anakanak Indonesia menjadi generasi emas yang cemerlang di masanya nanti. Generasi tersebut hendaknya berasaskan intelektualitas dan kompetensi yang kompetitif, keimanan dan ketaqwaan yang kokoh, senantiasa inovatif, kreatif, dan akomodatif terhadap beragam gejala kehidupan yang muncul di dalam masyarakat yang majemuk ${ }^{8}$. Selanjutnya, Kurikulum 2013 memiliki prinsip-prinsip yang harus dimunculkan pada setiap pembelajaran baik secara dokumentatif maupun operasional, adapun prinsip-prinsip tersebut diantaranya ${ }^{9}$;

${ }^{6}$ Mohammad Ansyar, Kurikulum Hakikat, Fondasi, Desain, dan Pengembangan, (Jakarta: Kencana, 2015), h. 262.

7 Sukmadinata, N.S. Kurikulum dan Pembelajaran Kompetensi (Bandung: Yayasan Kesuma Karya, 2004), h. 5

8 Surat Keputusan Menteri Agama Republik Indonesia, Implementasi Kurikulum 2013 di Madrasah, (KEMENAG RI, 2014), h. 4

9 Azkia Muharom al-Bantani, Implementasi Kurikulum 2013 Pada Pembelajaran Bahasa Arab di Madrasah Ibtidaiyyah dalam Arabiyat: Jurnal Pendidikan Bahasa Arab dan 
pembelajaran berbasis riset, sumber belajar yang beraneka ragam, pendekatan kontekstual, saintifik, dan integratif, pembelajaran berbasis kompetensi, dan penekanan adanya keseimbangan potensi fisikal dan mental yang harus dimunculkan oleh para siswa dalam proses pembelajaran.

Pembelajaran bahasa Arab di Indonesia memiliki empat tujuan penting yang harus diketahui secara seksama diantaranya adalah agama, pendidikan, ekonomi, sosial, dan budaya. Keempat tujuan tersebut memadu di setiap materi pembelajaran yang dicantumkan dalam bahan ajar bahasa Arab untuk sekolah maupun madrasah. Di sisi lain, perlu ditekankan pula mengenai kompetensi yang harus muncul seiring dengan tujuan tersebut yakni kompetensi berbahasa, komunikasi, dan budaya. Kompetensi pertama dipahami sebagai penguasaan tentang aspek-aspek bahasa secara baik dan benar yang meliputi fonetik, sintaksis, dan semantik. Kompetensi yang kedua dipahami sebagai kemampuan komunikatif dan interaktif melalui proses penyusunan kosakata yang mudah, lugas, dan sesuai kaidah berbahasa yang baik dan benar. Dan kompetensi yang ketiga adalah kemampuan para pembelajar bahasa dalam memahami unsur-unsur kebudayaan yang dibawa oleh bahasa tersebut untuk dapat dipelajari dan dikuasai secara baik dan benar ${ }^{10}$.

Pembelajaran bahasa Arab di madrasah aliyah dalam konteks kurikulum 2013 tentunya terdapat perbedaan tersendiri dibanding dengan kurikulum-kurikulum sebelumnya. Perbedaan tersebut dicirikan melalui konsep guru, sistem pembelajaran, dan siswa. Pada aspek pertama guru dalam konteks kurikulum 2013 merupakan

\footnotetext{
Kebahasaaraban Volume 2 Nomor 2 Tahun 2015, h. 181

${ }^{10}$ Abdurrahman al-Fauzan dkk. Durus al-Dauratal-Tadribiyah li Mua'allimial-Lugah al-Arabiyah li Ghairi al-Natihiqin Biha (al-Janib al-Nazhari) (tp: Mu'assasah al-Waqf alIslami, $1425 \mathrm{H})$, h. 27.
} 
fasilitator dan kolaborator yang baik bagi para siswa melalui proses bimbingan persuasif dalam bentuk transmisi pengetahuan yang terdapat dalam bahan ajar maupun mampu secara profesional memadukan unsur-unsur pengetahuan deskriptif dengan fenomena kehidupan yang memiliki keterkaitan erat dengan materi pembelajaran untuk dapat diambil substansinya atau nilai-nilai berharga bagi para siswa. Di sisi lain juga, dalam kurikulum 2013 guru dituntut untuk memiliki kompetensi untuk menguraikan dan mencari pengetahuanpengetahuan terbaru untuk membantu para siswa dalam pemahaman beragam gejala-gejala kehidupan yang dapat dibuka melalui kunci pengetahuan yang ada dalam materi pembelajaran. Aspek kedua adalah sistem pembelajaran yang diimplementasikan dengan menggunakan pendekatan saintifik. Pada jenjang sekolah menengah atas dan madrasah aliyah ataupun yang sederajat lainnya sistem pembelajaran ini tentunya mengelaborasi tiga aspek yakni sikap, keterampilan, dan pengetahuan. Pada aspek pertama, sikap yang harus dimiliki oleh para siswa adalah keimanan yang mapan, berakhlak mulia, bertanggung jawab dalam dinamika pergaulan di masyarakat, percaya diri dengan potensi yang dimiliki, dan menjadi bagian dari problem solver di tengahtengah hiruk pikuk problematika kehidupan. Aspek kedua adalah keterampilan yakni suatu kemampuan tindak tutur yang terpadu secara efektif, kreatif, dan interaktif melalui proses pembelajaran di dalam kelas dengan materi berbasis tematik dan kontekstual. Dan aspek yang ketiga adalah pengetahuan yakni serangkaian informasi keilmuan dalam materi pembelajaran yang merepresentasikan wawasan kemanusiaan, kebangsaan, kenegaraan, dan peradaban umat manusia pada umumnya melalui beragam kejadian dan fenomena yang nampak dalam dinamika kehidupan manusia ${ }^{11}$. Oleh karenanya,

${ }^{11}$ Yunus Abidin, Desain Sistem Pembelajaran dalam Konteks Kurikulum 2013, (Bandung: Refika Aditama, 2016), h. 58. 
indikator kelulusan siswa dari suatu mata pelajaran harus dintentukan oleh kemampuan untuk menalar, menganalisis, mengkomunikasi, dan mencipta dari hasil daya olah dan pikirnya selama mengikuti pembelajaran satu semester.

\section{Konstruktivisme dalam Kurikulum Bahasa Arab Madrasah Aliyah}

Pembelajaran bahasa Asing pada dasarnya membutuhkan pijakan kokoh yang mampu menjawab kebutuhan dan tantangan global yang dengan keragaman. Pijakan kokoh tersebut merupakan serangkaian teorisasi yang dilakukan oleh para pemerhati dan pakar untuk dapat menyesuaikan formulasi-formulasi pembelajaran yang dimulai dari kurikulum bahasa. Kontruktivisme dalam menginovasi kurikulum bahasa Arab memiliki prinsip dan tahapan dalam implementasinya. Konstruktivisme merupakan teori belajar yang dicetuskan oleh Jean Piaget yang berkebangsaan Swiss dengan menekankan pentingnya perkembangan kognitif pada siswa selama proses pembelajaran. Adapun perkembangan kognitif tersebut berprinsip pada beber aspek di antaranya ${ }^{12}$; Pertama, skema yakni sebuah kerangka konseptual yang terdapat dalam pikiran seorang siswa yang berfungsi untuk mengkategorikan dan mengintepretasikan beragam informasi yang menjadi pengetahuan. Piaget dalam konsep ini berpendapat bahwa skema akan senantiasa terwujud melalui proses organisasi pemahaman pengetahuan melalui beragam pengalaman yang diperoleh siswa dalam pembelajaran. Kedua, asimilasi merupakan proses masuknya pengetahuan baru ke dalam kognisi siswa yang sebelumnya dimasuki oleh pengetahuan-pengetahuan lainnya. Proses ini menghendaki adanya interpretasi, analisis, dan perumusan suatu pengetahuan yang diperoleh dengan mengubahnya menjadi pengetahuan baru yang

${ }^{12}$ John W. Santrock, Psikologi Pendidikan dialih bahasakan oleh Tri Wibowo B.S. (Jakarta: Kencana, 2010), h. 46-47. 
dipengaruhi oleh pengalaman-pengalaman atau kontekstualisasi yang bersifat situasional ${ }^{13}$. Ketiga, organisasi yakni proses pengelompokan perilaku atau cara pandang yang terpisah dalam suatu sistem kognisi yang teratur. Proses ini dilaksanakan secara berkesinambungan agar siswa dapat menanamkan pemahaman epistemologis dari hasil kajian ilmiah maupun eksperimen-eksperimen yang ia lakukan secara kolektif atau mandiri. Keempat, akomodasi adalah proses penyesuaian diri siswa dalam menerima pengetahuan melalui lingkungan belajar. Kelima, ekuilibrasi yakni proses mekanisme pengaturan diri untuk dapat mengelola asimilasi dan akomodasi agar menjadi seimbang dalam menghadapi problematika yang muncul saat berkomunikasi secara interaktif. Proses ini juga berfungsi membentuk pemulihan keseimbangan antara pemahaman terhadap pengetahuan baru dan lama yang didapat melalui beragam pengalaman dalam pembelajaran.

Kontruktivisme kognitif yang digagas oleh Jean Piaget menekankan pentingnya para pembelajar untuk senantiasa aktif mencari solusi secara mandiri melalui materi-materi pembelajaran yang diajarkan oleh guru di kelas. Siswa diarahkan untuk mampu menemukan, menguraikan, dan mendiskusikannya dengan teman-teman mereka melalui pembelajaran kooperatif, kolaboratif, dan interaktif. Guru dalam teori ini berfungsi sebagai fasilitator dan mitra belajar yang kolaboratif dengan menekankan proses belajar dengan beraktivitas (learning by doing). Guru senantiasa menyimak, mengamati, dan memberikan beberapa pertanyaan yang berguna untuk mengokohkan hasil penemuan siswa dan mengukur tingkat pemahaman terhadap apa yang mereka temukan. Oleh karenanya, para guru hendaknya mampu mengelola dan mengatur kelas pembelajaran menjadi ruang eksplorasi pengetahuan baru sehingga para siswa menjadi seorang

${ }^{13}$ Dale H. Schunk, Learning Theories An Educational Perspective, (Yogyakarta: Pustaka Pelajar, 2012), h. 331. 
peneliti sekaligus menjadi guru yang interaktif bagi teman sebayanya dalam proses pembelajaran.

Kontribusi konstruktivisme KognitifJean Piaget terhadap inovasi kurikulum bahasa Arab di Madrasah Aliyah dapat difomulasikan melalui tiga landasan penting dalam pembentukan pengetahuan siswa yang diantaranya ${ }^{14}$; pertama, pengetahuan fisik (phisycal knowledge) yakni pengetahuan tentang kosakata-kosakata sederhana dan aplikatif dalam situasi dan kondisi yang dibutuhkan atau pengetahuan kebahasaan yang difungsikan untuk komunikasi interaktif melalui pembelajaran di kelas. Kedua, pengetahuan logika-matematika (logicomathematicalknowledge) yakni sebuah konstruksi pemahaman tentang pengetahuan yang didapat melalui hasil kajian eksperimentasi maupun diskusi interaktif oleh para pembelajar yang hasilnya memiliki relasi dengan tuntutan dan kebutuhan zaman. Ketiga, pengetahuan sosial (social knowledge) yakni pengetahuan yang disusun melalui proses komunikasi interaktif yang dilakukan oleh siswa pembelajaran di kelas. Pengetahuan sosial menghendaki adanya aspek empiris dalam penyusunan pengetahuan-pengetahuan yang tentunya diperoleh siswa melalui serangkaian pengelaman selama belajar baik secara mandiri maupun berkelompok.Jean Piaget tidak hanya memfokuskan kajiannya dalam bidang kognitif. Di bidang afektif ia memberikan penjelasan bahwa proses afektifnya pembelajar senantiasa ada melalui adaptasi yang berkelanjutan yang diindikasikan dengan adanya ekspresi diri terhadap bakat dan minat yang dimiliki melalui pengaturan sistem kognisi yang terstruktur ${ }^{15}$. Oleh karenanya, dalam proses inovasi kurikulum bahasa Arab tentunya harus mengedepankan beberapa

${ }^{14}$ Ratna Wilis Dahar, Teori-Teori Belajar dan Pembelajaran, (Jakarta: Erlangga, 2011), h. 143 .

${ }^{15}$ Sri Wulandari Danoebroto, Teori Belajar Konstruktivis Piaget dan Vygotsky, dalam Journal Of Mathematic and Education Volume 2 Nomor 3 Tahun 2015, h. 192. 
prinsip yakni relevansi, fleksibilitas, kontinuitas, praktis, dan efektif. Kelima prinsip tersebut haruslah diletakkan dalam kerangka ide dan tujuan inovasi kurikulum yang tentunya tidak mengubah substansi kurikulum yang telah dibentuk dan dilegitimasi sehingga penyesuaian kurikulum dengan tuntutan dan kebutuhan masyarakat luas telah diakomodasi oleh institusi pendidikan yang kemudian dibuatlah proses penjabaran-penjabaran dalam bentuk silabus dan rencana pelaksanaan pembelajaran oleh para guru.

Pembaharuan kurikulum menjadi hal terpenting di tengahtengah modernisasi segala bidang. Kurikulum bahasa Arab hendaknya mampu menempatkan bahasa Arab sebagai ujung tombak komunikasi dua arah yang saling beriringan yakni komunikasi dalam bidang pembelajaran yang memfungsikan bahasa Arab sebagai key of knowledge untuk mempelajari ajaran Islam. Selain itu juga komunikasi dalam bidang diplomasi atau pergaulan internasional yang menjadikan bahasa Arab sebagai bahasa politik, keamanan dan ekonomi negaranegara timur tengah yang kini sedang mengalami perkembangan dari segala lini. Dalam aliran progresivisme inovasi kurikulum bersifat buttom up yakni inovasi yang dimulai dari para pendidik yang memberikan kontribusi dan ide untuk mengubah kurikulum yang didasarkan atas beragam pengalaman saat mengelola pembelajaran di kelas. Antara progresivisme dan konstruktivisme memiliki relasi yang kuat untuk membangun rancangan kurikulum yang berpusat dapat para pembelajar bahasa. Progresivisme menghendaki adanya proses pertumbuhan individu yang distimulus oleh komunikasi interaktif dalam lingkungan belajar yang baik, menyenangkan, dan saling menguntungkan para pembelajar, menekankan pentingnya pemerolehan pengalaman melalui pembelajaran di kelas, menjadikan pembelajar sebagai manusia yang utuh dengan jiwa dan raganya, 
dan mengajarkan pentingnya tanggung jawab dalam pemerolehan informasi dan menyuguhkannya secara baik dan benar atau objektif ${ }^{16}$.

\section{Simpulan}

Berdasarkan penjelasan tersebut maka didapatlah beberapa kesimpulan yang diantaranaya;

1. Kurikulum merupakan pedoman pembelajaran yang didasarkan pada rancangan sistematik dan koordinatif yang bertujuan untuk menghasilkan output pembelajaran yang disepakati dalam suatu sistem pendidikan. Kurikulum 2013 untuk madrasah aliyah merupakan pembaharuan kurikulum sebelumnya yang bertujuan untuk mengembangkan potensi peserta didik agar memiliki problem solver yang produktif, inovatif, dan akomodatif terhadap tantangan dan kebutuhan zaman.

2. Konstruktivisme merupakan serangkaian konstruksi pengetahuan yang diperoleh dan digunakan oleh manusia sebagai hasil ijtihad ilmiah rasionalistis yang disebabkan oleh realita konstruksi kognitif melalui aktivitas-aktivitas eksperimentatif oleh manusia melalui bidang tertentu. Belajar dalam perspektif ini merupakan proses membangun pengetahuan yang didasarkan dengan realita pengalaman yang ada di lingkungan sekitar. Proses ini membutuhkan basis kognisi yang kokoh untuk membangun pengetahuan-pengetahuan yang didapat melalui pengalaman belajar.

3. Inovasi kurikulum bahasa Arab berbasis konstruktivisme adalah dengan berpijak pada konsep perkembangan kognitif Jean Piaget

16 Henry Guntur Tarigan, Dasar-Dasar Kurikulum Bahasa, (Bandung: Angkasa, 2009), h. 130. 
yakni pengetahuan fisik (phisycal knowledge) yakni pengetahuan tentang kosakata-kosakata sederhana dan aplikatif dalam situasi dan kondisi yang dibutuhkan atau pengetahuan kebahasaan yang difungsikan untuk komunikasi interaktif melalui pembelajaran di kelas, pengetahuan logika-matematika (logico-mathematical knowledge) yakni sebuah konstruksi pemahaman tentang pengetahuan yang didapat melalui hasil kajian eksperimentasi maupun diskusi interaktif oleh para pembelajar yang hasilnya memiliki relasi dengan tuntutan dan kebutuhan zaman, dan pengetahuan sosial (social knowledge) yakni pengetahuan yang disusun melalui proses komunikasi interaktif yang dilakukan oleh siswa pembelajaran di kelas.

\section{DAFTAR PUSTAKA}

Abdurrahman al-Fauzan dkk,.Durus al-Dauratal-Tadribiyah li Mua'allimi al-Lugah al-Arabiyah li Ghairi al-Natihiqin Biha (al-Janib al-Nazhari), tp: Mu 'assasah al-Waqf al-Islami, $1425 \mathrm{H}$.

Abidin, Yunus, Desain Sistem Pembelajaran dalam Konteks Kurikulum 2013, Bandung: Refika Aditama, 2016.

al-Bantani, Azkia Muharom. Implementasi Kurikulum 2013 Pada Pembelajaran Bahasa Arab di Madrasah Ibtidaiyyah dalam Arabiyat: Jurnal Pendidikan Bahasa Arab dan Kebahasaaraban Volume 2 Nomoro 2, 2015.

Ansyar, Mohammad, Kurikulum Hakikat, Fondasi, Desain, dan Pengembangan, Jakarta: Kencana, 2015.

Danoebroto, Sri Wulandari, 2015. Teori Belajar Konstruktivis Piaget dan Vygotsky, dalam Journal Of Mathematic and Education Volume 2 Nomor 3 
Daryanto, Pendekatan Pembelajaran Saintifik Kurikulum 2013, Yogyakarta: Gava Media, 2014.

Direktorat Pendidikan Madrasah Kemenag RI, Durūsu al-Lughah al'Arabiyyah Buku Guru Bahasa Arab Pendekatan Saintifik Kurikulum 2013 untuk Kelas X Madrasah Aliyah, Jakarta: Dirjen Pendidikan Madrasah Kemenag RI, 2014.

H. Schunk, Dale, Learning Theories An Educational Perspective, Yogyakarta: Pustaka Pelajar, 2012.

Muhajir, Śulāsiyah al-'Uqul Nabil Ali Sebagai Epistemologi Kurikulum Bahasa Arab di Indonesia (Perspektif Struktural-Fungsional), Disertasi, Yogyakarta: Program Pascarsarjana UIN Sunan Kalijaga Yogyakarta, 2015.

N.S, Sukmadinata, Kurikulum dan Pembelajaran Kompetensi, Bandung: Yayasan Kesuma Karya, 2004.

Suparno, Paul, Filsafat Konstruktivisme dalam Pendidikan, Yogyakarta: Kanisius

Surat Keputusan Menteri Agama Republik Indonesia, 2014. Implementasi Kurikulum 2013 di Madrasah, KEMENAG RI, 1997.

Tarigan, Henry Guntur, Dasar-Dasar Kurikulum Bahasa, Bandung: Angkasa, 2009.

W. Santrock, John, Psikologi Pendidikan dialih bahasakan oleh Tri Wibowo B.S., Jakarta: Kencana, 2010.

Wilis Dahar, Ratna, Teori-Teori Belajar dan Pembelajaran, Jakarta: Erlangga, 2011. 